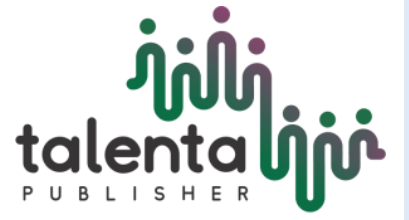

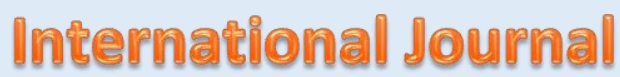

of Ecophysiology

\title{
Type of helminth parasite in Snakehead fish (Channa striata) from Seuneubok Cina, Indra Makmur, Aceh Timur, Indonesia
}

\author{
Masitta Tanjung ${ }^{1,2 *}$, Nursal $^{1}$ and Siti Karimah ${ }^{1}$ \\ ${ }^{1}$ Department of Biology, Faculty of Mathematics and Natural Sciences Universitas Sumatera Utara. \\ Medan, North Sumatera, Indonesia. \\ Jl. Bioteknologi No. 1 Kampus USU Padang Bulan, Medan, North Sumatera 20155, Indonesia \\ ${ }^{2}$ Center of Excellence for Natural Resources-Based Technology, Mangrove and Bio-Resources Group \\ Universitas Sumatera Utara, Medan, North Sumatera 20155, Indonesia
}

\begin{abstract}
Snakehead fish (Channa striata) is one of the freshwater fish in tropical regions such as Asia and Africa, and has high nutrition but is difficult to cultivate. In Indonesia, Snakehead fish are found in paddy fields, swamps and ditches, making them susceptible to parasites. Constraints in Snakehead fish cultivation are caused by the nature of the fish as a predatory, lack of the availability of food and environmental conditions that can affect the growth of the fish. The former paddy fields in Seuneubok Cina of Indra Makmur, Aceh Timur, Indonesia, is found many Snakehead fish. This research aims to determine the types of parasites that infect Snakehead fish. The Snakehead fish was taken using electrofishing gear with purposive sampling method, then dissected and identified the endoparasites which contained in the fish intestines. The research results found three genus of parasites: Pallisentis, Procamallanus and Camallanus.
\end{abstract}

Keywords: Channa striata, camallanus, endoparasit, pallisentis, procamallanus

Received 17 November 2018| Revised 24 December 2018 | Accepted 28 January 2019

\section{Introduction}

Fish in swamp waters can be grouped into two groups, white color fish (Whitefishes) and black color fish (Blackfishes). One example of swamp fish is Snakehead fish. Snakehead fish is one of the endemic swamp fish species whose presence is decreasing. Snakehead fish (Channa striata) is a swamp fish that has not been widely cultivated. Snakehead fish cultivating has not given a maximum result, because these fish are predatory, lack of suitable feed

\footnotetext{
*Corresponding author at: Jl. Dr. Mansyur, Medan, Indonesia

E-mail address: masittatanjung@yahoo.co.id
} 
availablity and environmental conditions that must be in accordance with the growth of this fish. Snakehead fish is found in paddy fields or rainfed (Amilhat, E. and Lorenzen, 2005), swamps and ditches. Such environmental conditions causing Snakehead fish to be susceptible to ectoparasites such as Argulus nobilis as the main species of ectoparasites in channa striata fish (Rajiv, Ravi, and Zahaya. 2011).

Fish disease is mostly caused by contamination from outside (external) or environmental changes (Khan, 2012), both infectious and non-infectious. Worm infections often become disease agents in the gills, digestive tract, and fish muscles. Channa striata has been widely investigated in Bangladesh (Bashirullah, A.K.M. 1973; Ahmed, 1981; Arthur, and Ahmed, 2002; Ghani, and Bhuiyan 2011), Nigeria (Esther, Daniel, and Chris, 2015) and India (Bhattacharya, 2007). Snakehead fish are in great demand and consumed by humans as a source of protein, because the levels of protein found in the fish such as albumin and zinc are quite high (Mustafa, Widodo, and Kristianto, 2012 ). Albumin is useful for the formation of new cells and replacing damaged cells, so that in Indonesia this fish becomes the consumption of sick people to accelerate wound healing.

Snakehead fish habitat is very influential on the growth of parasites so that it can reduce production and eventually cause losses. Parasites found in freshwater fish are trematode (monogenea and digenea), cestoda, nematode and acanthocephalans which complete their life cycle (Schmidt, 1990). In Singapore, Malacca and Seremban were found 16 species of worm such as Senga malayana $\mathrm{n}$. sp. from the small intestine Channa striata and S. ophicephaliana, $S$. parva n.sp. from the intestine of C. micropeltes resembling S. lucknowensis. S. filiformis n.sp. from the intestine of $C$. micropeltes. Camallanus yehi n.sp. from the intestine of Channa striata resembles Camallanus ophicephali. C. longitridentatus n.sp. from Clarias batrachus and Procamallanus malaccensis n. sp. from the intestines of Channa lucius (Fernando, and Furtado, 1964). The four infected worms found in Channa striata were: Cestoda, Bothriocephalus cuspidatus, Nematoda, Ascaridia spp. and Camallanus intestinalus and one Acanthocephala; Pallisentis ophiocephali (Kundu and Bhuiyan, 2016).

\section{Materials and Methods}

Snakehead fish samples were taken from the swamps of the villager's paddy fields in the area of Seuneubuk Cina, Indra Makmur, Aceh Timur, Indonesia, the swamp area was around $20 \mathrm{x} 15 \mathrm{~m}$, the bottom of the swamp was a mud with a depth of about $1.5 \mathrm{~m}$. The sampling of Snakehead fish (Channa striata) was carried out by purposive sampling method, that is by making a shock around the former paddy fields, using electrofishing equipment and fish affected by shocks will appear on the surface of the water, then put in a plastic bag filled with air, 1 plastic bag containing 4-5 fish and this sampling was carried out 4 days. 


\section{Examination of Parasitic Worms in the Fish Digestive Tract}

Fish organs to be examined are the digestive tract (intestine). Examination of the organs in the fish's body is done by dissecting the body parts of the fish from the cloaca to the pectoral part, then the intestinal organs are removed from the fish's body and placed in a petri dish containing $0.85 \% \mathrm{NaCl}$ then observed under a microscope. The examination of intestinal contents is by removing the intestinal contents by dissecting or cutting the intestines vertically. Intestinal contents are taken little by little and placed on a glass of object, then dripped with $0.85 \% \mathrm{NaCl}$ solution and then closed using a cover glass. Observations were made under a microscope and using a digital camera, then an examination of the intestinal wall was carried out after all the intestinal contents were removed, then a thinly sliced intestine with a length of $0.5 \mathrm{~cm}$ was placed in a petri and dripped with $0.85 \% \mathrm{NaCl}$ solution and observed throughout the intestinal wall under a microscope. Parasitic identification was carried out using the Yamaguti (2063), and the terminology refers to Margolis et al. (1982).

\section{Results and Discussion}

The type of parasite in the digestive tract of Snakehead fish in the Seuneubok Cina, Indra Makmur, Aceh Timur, Indonesia obtained 3 parasite genus :

\section{a. Pallisentis}

Worms found in the digestive tract of Snakehead fish precisely in the contents of the intestine are Pallisentis those identified by the characteristics of the elongated body with a proboscis, the lines on the neck are clearly visible, proboscis and fibers in the proboscis are seen more than other parasites, and the body parts have horns, Pallisentis body is muttered and can be seen in Figure 1.

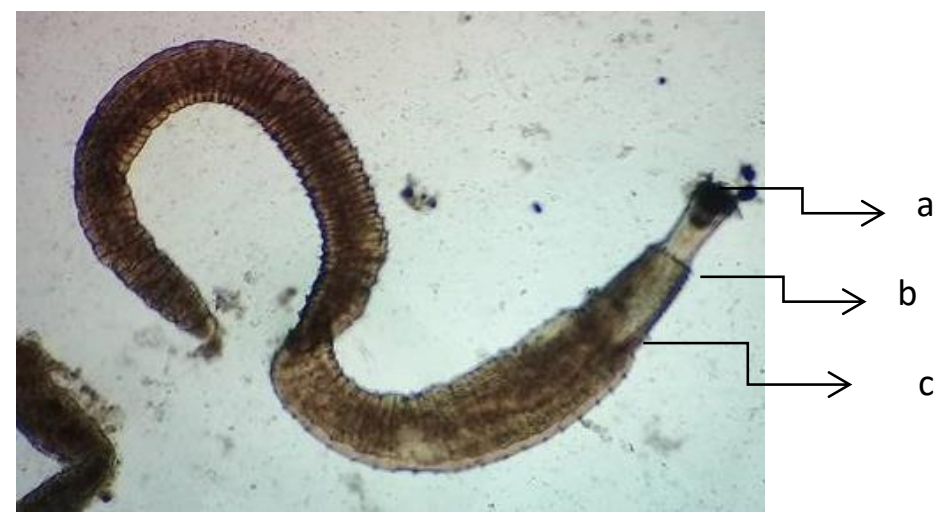

Figure 1. Pallisentis which infects Snakehead fish (C. Striata) in the Seuneubok Cina, Indra Makmur, Aceh Timur, Indonesia in $0.85 \% \mathrm{NaCl},(10 \times 40)$ a. proboscis; b. neck; c. body. 
Pallisentis has a body extending around $10.20-22.94 \mathrm{~mm}$ in width $0.36-0.65 \mathrm{~mm}$ in females while in males it is about 7.88-12.20mm in length and $0.40-0.46 \mathrm{~mm}$ in width, there are 8-9 spiral lines hooks with four hooks each have a cuticle, and 35-50 rows of posterior spiral rods like rods without spinulation. Acanthocephala is characterized by ducted thorn rods, proboscic has 4 circles of 10 hooks each, with hooks in the anterior circle 2 being much larger than the posterior circle 2. Y-shaped thorns are channeled into 2 regions separated by an infinite zone. The anterior neck spines are in a complete circle of 9-17 tightly spaced thorns and the larger posterior stem spines are in the 1 (posterior) to 41 (anterior) circles extending to the level of the cement glands in the posterior males, a considerable variation of the original description and new structure (Amin et al., 2000).

The Pallisentis classification is: Animalia (Kingdom); acanthocephala (Phylum); Eoacanthocephala (Class); Gyracanthocephala (Order); Quadrigyridae (Family); Pallisentinae (Subfamily); Pallisentis (Genus) (Amin et al., 2000). Pallisentis new species are based on LM and SEM described from sexual diversity in hook and spinal structures (Gupta, Gupta, and Singhal, 2016). There is found a Pallisentis rexus n. sp. worm type in fresh water snakehead, Channa striata Bloch, from the Chiang Mai Basin (Wongkham and Whitfield, 2004). The other Pallisentis species found in India are Pallisentis jagani sp. from Channa channa's intestine (Koul et al., 1991).

In India the parasitic acanthocephala type Pallisentis is reported to have 20 species (Bhattacharya, 2007). The Pallisentis genus is acanthocephala endoparasites that inhabit the intestinal wall (Gupta, Gupta, and Singhal, 2016) Ordinary Pallisentis characterized by proboscis hook size sub genetically divided into 19 species (Amin et al., 2000).

\section{b. Procamallanus}

Procamallanus those found based on dark brown characteristics, body covered with cuticles, digestive tract clearly visible (brown-black), female body size is smaller than male, in males longer than females and male tail tips are sharp mouthpieces and have oral cavity wide (Figure 2). 


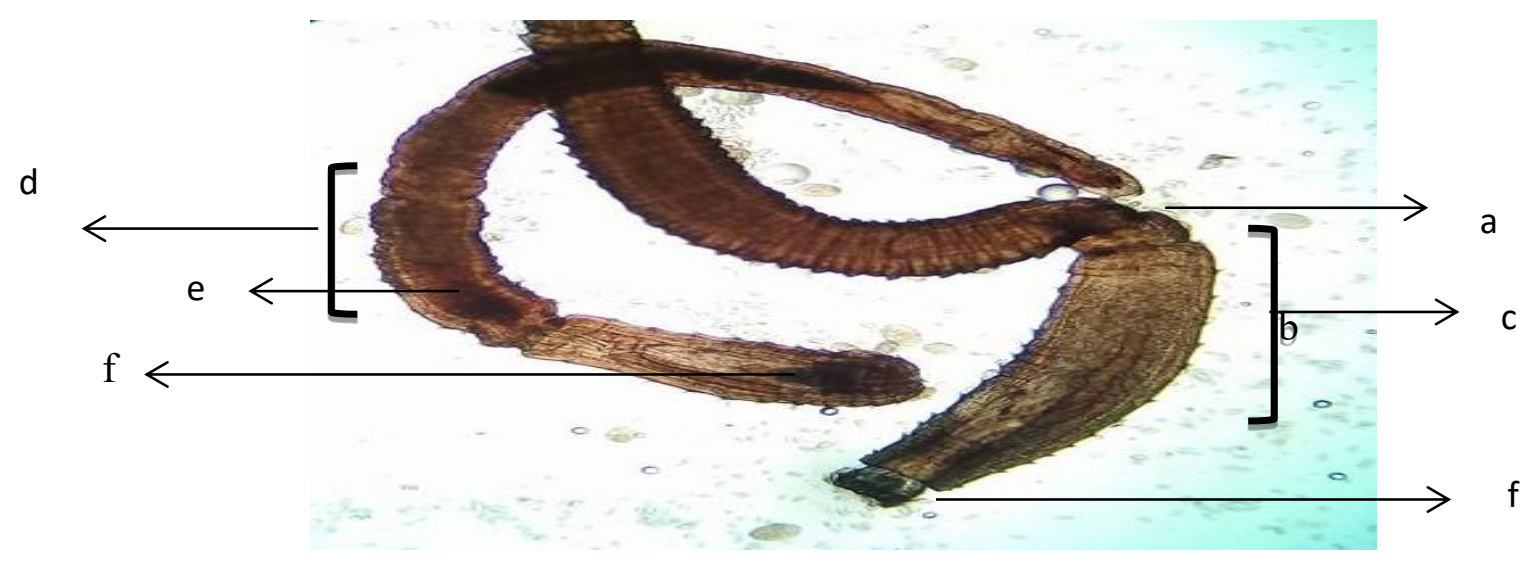

Figure 2. Procamallanus found in Snakehead fish (C. Striata) in the Seuneubok Cina, Indra Makmur, Aceh Timur, Indonesia in $0.85 \% \mathrm{NaCl} \quad(10 \mathrm{x} 40) \quad$ a. Procamallanus male, b. Procamallanus female, c. digestive tract, d. oral cavity, e. male tails, f. buccal capsules.

The genus Procamallanus has a buccal capsule not clearly visible like Camallanus. Procamallanus's mouth is usually hexagonal with six papillae that have not been fully formed on the edge of the mouth and there are four large papillae located mid-anterior, the esophagus consists of two parts, anterior and posterior. Classification of Procamallanus Kingdom: Animalia, Phylum: Platyhelminthes, Class: Nematodes, Family: Camallanidae, Genus: Procamallanus. Procamallanus sp. is a new species of nematode. Procamallanus (Procamallanus) pacificus n. sp., found from the stomach of the Pacific ocean (Moravec, 2006). Pallasentis found on Oreochromis niloticus and Clarias gariepinus (Domo, and Ester, 2015).

\section{c. Camallanus}

Camallanus found in the digestive tract organs of Snakehead fish (C. Striata) identified by the presence of cavity capsules covered with cuticles, the mouth is like a strong clamp that is surrounded by a horn, the digestive tract is clearly visible on the body part of dark brown and the muscle part is clearly visible, the body is muttered with a clear line and is brown. Female Camallanus has a conical tail without mucosa, not having a well developed vulva lips (Figure $3)$. 


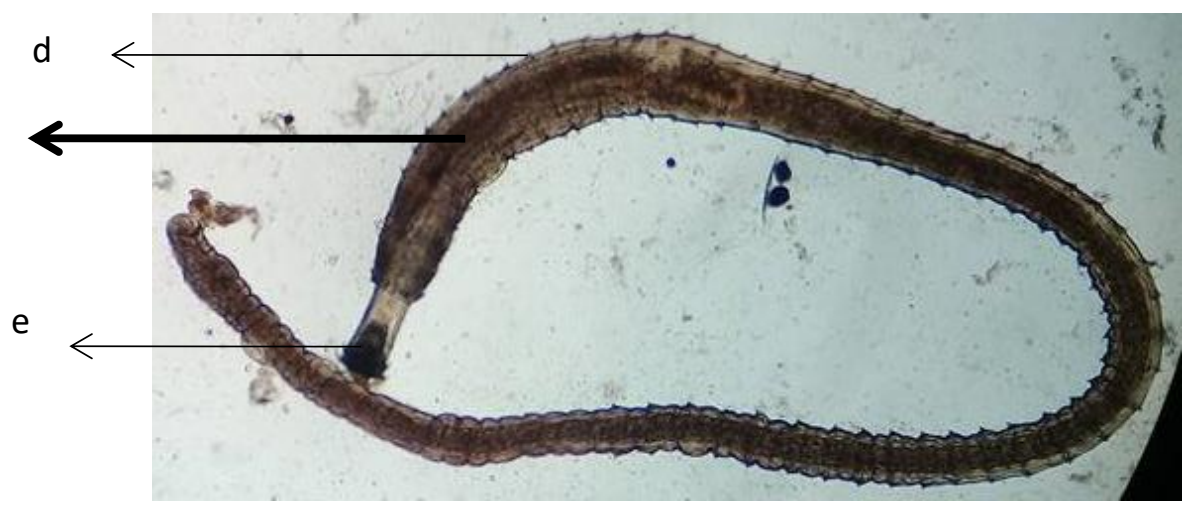

Figure 3. Camallanus which is found in the digestive tract of Snakehead fish in the Seuneubok Cina, Indra Makmur, Aceh Timur, Indpnesia in 0.85\% $\mathrm{NaCl}(10 x 40$ a. muscle b. intestinal part c. capsule cavity.

A new species of Camallanus in freshwater Trachemys dorbigni turtles. The new parasite species of Callallanus is described as Camallanus emydidius n. sp. This new species is different from other freshwater species mainly due to the morphology of the right spicule, the number of precloacal and postcloacal male papillae, and the presence of "mucosa" in the female posterior extremity (Mascarenhas and Muller, 2017). Fish farming (Xiphophorus maculates) (Osteichthyes: Poecilidae) in São Paulo State, Brazil was also attacked by Camallanus maculatus n. Sp. (Nematodes: Camallanidae) (Martins et al.,, 2007). Camallanus tridentatus is found from the stomach, caeca and intestine of naturally infected Arapaima gigas from Mexiana Island, Amazon River Delta, Brazil (Santo and Moravec, 2009). Camallanus sp. and Ligula intestinalis from fresh E. sardella (Mgwede and Msiska, 2018). Camallanus polypteri n. sp. obtained from Polypterus bichir, Synodontis schall and Clarias anguillaris in Lake Tingrela, Burkina Faso is different from other African species from the subfamily Camallaninae parasitic freshwater fish, because they do not have tridents (Kabre and Petter, 1997).

Camallanus sp has the characteristics of a capsule cavity, blood sucking habit that causes anemia, and attachment to the cavity of the capsule causes erosion of the mucosa. The life cycle of this species can develop in the aquarium because it can produce active larvae, so this parasite does not require a host for its survival. This parasite attacks the intestine and can infect the caecal pylorus. Camallanus sp. attack many ovipar fish species. Classification of Camallanus into subfamily Camallaninae (Chakravarty and Majumdar, 1960). Genus: Camallanus, Species: Camallanus sp.

Ectos and endoparasites in Channa punctatus have parasites such as protozoa, platyhelminth, nematodes, acanthocephala, arthropods, gastrotricha and rotifer. Overall the incidence of infection in Channa punctatus was higher (60.00\%) of protozoa parasites. The highest incidence o protozoan parasite infection was recorded at $60.00 \%$ in 2007 in open water 
samples. On the other hand, the highest incidence of infection in closed water is $75 \%$ of the platyhelminth parasites. Found two new species (Rotifer and Chaetonotus sp.) are new parasites in Channa punctatus (Miah et al., 2013). In the Parachanna obscura, were also found nematode parasites (Esther, Daniel, and Chris, 2015).

\section{Conclusion}

The type of parasitic worm found in the digestive tract of Snakehead fish (Channa striata) in the village of Seuneubok Cina, Indra Makmur, Aceh Timur, Indonesia, is from the Ecanthocephala class i.e. the Pallissentis whereas from the Nematode class there are two types of Procamallanus and Camallanus.

\section{Reference}

[1] Ahmed, A.T.A. 1981. Helminth infection in freshwater fishes of Bangladesh. Fish Pathology 15 (3/4): 229-236.

[2] Amilhat, E. and Lorenzen, K. 2005. Habitat use, migration pattern and population dynamics of chevron snakehead Channa striata in a rainfed rice farming landscape. Journal of fish biology. 67(sB):23-34.

[3] Amin, O.M., Heckmann, R.A., Van Ha. N., Van Luc, P., Doanh, P.N. 2000. Revision of the genus Pallisentis (Acanthocephala: Quadrigyridae) with the erection of three new subgenera, the description of Pallisentis (Brevitritospinus) vietnamensis subgen. et sp. n., a key to species of Pallisentis, and the description of a new Quadrigyrid genus, Pararaosentisgen. n. Comp Parasitol. 67: 40-50.

[4] Arthur, J.R. and Ahmed, A.T.A. 2002. Checklist of the parasites of fishes of Bangladesh. FAO, FTP 369/1: 77.

[5] Bashirullah, A.K.M. 1973. A brief survey of the helminth fauna of certain marine and fresh water fishes of Bangladesh. Bangladesh J. Zool. 1(1): 63-81.

[6] Bhattacharya, S.B. (2007). Handbook on Indian Acanthocephala. Editorial: ZSI, Kolkata, 2007 ISBN 10: 8181711386 / ISBN 13: 9788181711380.

[7] Chakravarty, G. K. and Majumdar, G. 1960. On the classification of the nematode family Camallanidae Railliet and Henry 1915. Indian Journal of Helminthology . 12(2):93-94

[8] Domo, G.A and Ester, S.T. 2015. Prevalence of the helminth parasites of Oreochromis niloticus and Clarias gariepinus in lake Geriyo Jimeta Yola, Adamawa State. J Nov. Appl Sci., 4(1):1-6.

[9] Esther M. O., Daniel, A.A. and Chris, N. 2015. Incidence of nematode parasites in snakehead, Parachanna obscura of the lower Cross river system, Nigeria. International Journal of Fisheries and Aquatic Studies. 2(4):331-336. 
[10] Fernando, C.H. and Furtado, J.I. 1964. Helminth parasites of some Malayan fresh-water fishes. Bulletin of the Natiopnal Museum, state of Singapore. No. 32. 45-71pp.

[11] Ghani, M.O. and Bhuiyan, A.I. 2011. Community structures of endoparasitic helminths of Channa punctatus from a freshwater river and a polluated lagoon of Bangladesh. Bangladesh J. Zool. 39(2):173-185.

[12] Gupta, N., Gupta, D.K., and Singhal, P. 2016. Description of Pallisentis (Brevitritospinus) punctati n. sp. (Acanthocephala: Quadrigyridae) from Channa punctatus in Bareilly, Uttar Pradesh, India. Iran J.parasitol. 10(4): 605-616.

[13] Kabre, G.B. and Petter, A.J. 1997. Camallanus polypteri n. sp. (Nematoda: Camallanidae) in freshwater fishes from Burkina Faso. Onderstepoort Journal of Veterinary Research, 64:33-37

[14] Khan, R.A. 2012. Host-parasite interactions in some fish species. J. Parasitol. Research 7, Article ID 237280.

[15] Koul, P. L., Raina, M. K., Bambroo, P. and Koul, U. 1991. Pallisentis jagani sp. nov. from Channa channa in Jammu. Indian Journal of Helminthology. 43(2):124-136.

[16] Kundu, S and Bhuiyan, A.I. 2016. Abundance of helminth parasite in channa striatus (bloch, 1793) from Punarbhaba and Atrai rivers . Dhaka Univ. J. Biol. Sci. 25(1):39-46.

[17] Margolis, L., G.W. Esch, J.C. Holmes, A.M. Kuris and G.A. Schad, 1982. The use of ecological terms in parasitology (report of an ad hoc committee of the American Society of Parasitologists). J. Parasitol. 68(1):131-133.

[18] Martins, M.L., Garcia, F., Piazza, R.S. and Ghiraldelli, L. 2007, Camallanus maculatus n. sp. (Nematoda: Camallanidae) in an ornamental fish Xiphophorus maculatus (Osteichthyes: Poeciliidae) cultivated in São Paulo State, Brazil Arq. Bras. Med. Vet. Zootec., 59(5):1224-1230.

[19] Mascarenhas, C. S. and Muller, G. 2017.Camallanus emydidius n sp. (Nematoda Camallanidae) In Trachemys dorbigni (Dumeril \& Bibron:1835) Testudines: Emydidae From Southern Brazil. International Journal For Parasitology: Parasites and Wildlife. 6:108-114.

[20] Mgwede C.W., and Msiska O. 2018 Determination of seasonal occurrence of Camallanus sp. and Ligula intestinalis on fresh Usipa, Engraulicypris sardella from selected Mzuzu markets, Malawi, International Journal of Aquaculture, $8(5): 29-37$

[21] Miah, F., Deb, M., Ali, H., Quddus, M. M. A. and Ahmed, K. 2013. Comparative Surveillance of Parasitic Infestation in Channa punctatus (Osteichthys: Channidae) Advances in Zoology and Botany 1(1):17-23. 
[22] Moravec, F. Justine, J.L., Wurtz, J., Taraschewski H. and sasal, P. 2006. A New Species Of Procamallanus (Nematoda: Camallanidae) From Pacific Eels Anguilla spp). J. Parasitol. 92(1):130-137.

[23] Mustafa, A., Widodo, M.A. and Kristianto, Y. 2012. Medical and Health Science 1 Albumin and Zinc Content Of Snakehead Fish (Channa striata) Extract And Its Role In Health. IEESE International Journal of Science and Technology (IJSTE). 1(2):2252-5297.

[24] Rajiv, A., L. Ravi, and Z.S. Zahaya. 2011. Identification of Parasitic Abundance and Molecular Studies of Haruan (Channa Striata). Aquocukcute on the community:USM-CTU. Seminar and Presentation Compilation. 51.

[25] Santo, C.P. and F. Moravec, 2009. Camallanus tridentatus (Drasche) (Nematoda: Camallanidae):new taxonomically important morphological data. Mem Inst Oswaldo Cruz, Rio de Janeiro, 104(1):93-99.

[26] Schmidt GD 1990. Essentials of Parasitology (4th ed.). W.M.C. Brown Publishers, Texas, USA.

[27] Wongkham, W. and Whitfield, P.J. 2004. Pallisentis rexus from the Chiang Mai Basin, Thailand: ultrastructural studies on egg envelope development and the mechanism of egg expansion. J. Helminthol. 78(1):77-85.

[28] Yamaguti, S. 1963. Systema Helminthum. Acanthocephala. Int. Book \& Periodicals Supply Service, New Delhi, India. 